\title{
Effect of Formulations of Allyl Isothiocyanate on Survival of Macrophomina phaseolina from Strawberry
}

Juliana S. Baggio, University of Florida, Gulf Coast Research and Education Center, Wimauma, 33598; Manuel Chamorro, Driscoll's of Europe, Moguer, Huelva, Spain; Leandro G. Cordova, University of Florida, Gulf Coast Research and Education Center, Wimauma, 33598; Joseph W. Noling, Citrus Research and Education Center, Lake Alfred, FL, 33850; and Gary E. Vallad and Natalia A. Peres, ${ }^{\dagger}$ Uni- $^{-}$ versity of Florida, Gulf Coast Research and Education Center, Wimauma, 33598

\begin{abstract}
Management of Macrophomina phaseolina, causal agent of charcoal rot in many crops worldwide, including strawberry, has become more challenging since the phase out of methyl bromide (MeBr). The search for a fumigant equally effective as $\mathrm{MeBr}$ to control soilborne pathogens has been extensive. Allyl isothiocyanate (AITC), a biofumigant recently registered in the United States, was evaluated at different rates, formulations, fumigant combinations, and application methods in the fall of 2014 and 2015 at two research facilities in Balm and Dover, FL. The efficacy of treatments was determined by

evaluating the survival of $M$. phaseolina inoculum on infested corn-cob litter buried in bags 7.6 and $20.3 \mathrm{~cm}$ deep in the center, and $7.6 \mathrm{~cm}$ deep in the side, of plastic mulched raised beds. The biofumigant was shown to be more or as effective in reducing populations of $M$. phaseolina in the soil compared with standard fumigants, such as chloropicrin and 1,3-dichloropropene with chloropicrin. Thus, AITC is a promising biofumigant alternative for managing charcoal rot of strawberry, particularly in organic production systems, and should be evaluated for the management of other soilborne pathogens.
\end{abstract}

Macrophomina phaseolina (Tassi) Goidanich, causal agent of charcoal rot in many crops worldwide, has become more prevalent since the phase out of methyl bromide (MeBr) (Mertely et al. 2005; Zveibil and Freeman 2005). The pathogen has a host range of more than 500 plant species and can cause serious economic losses to agricultural crops of beans, cereals, cotton, cucurbits, soybeans, and strawberry (Dhingra and Sinclair 1978; Gupta et al. 2012; Mertely et al. 2005; Mihail 1992; Su et al. 2001). In strawberry, Florida growers reported $30 \%$ losses in mortality of early season plant stands (Chamorro et al. 2016).

M. phaseolina can overwinter in the soil by producing resistant structures, microsclerotia formed in epidermal and vascular tissues of its host during parasitic phases that are then released into the soil upon disintegration of host, which facilitate its long-term survival and dispersal (Dhingra and Sinclair 1975; Zveibil et al. 2012). Microsclerotia present in crop debris and soil are usually the primary source of inoculum, and populations increase in soils when susceptible hosts are grown continuously for several seasons (Dhingra and Sinclair 1978; Short et al. 1978). High temperatures, soil water deficit, high soil carbon-to-nitrogen ratios, monoculture, and sandy soils usually favor microsclerotia survival and enhance disease development (Dhingra and Sinclair 1975; Mihail 1989; Zveibil et al. 2012). Infection of plants usually occurs by sclerotia germination, favored by temperatures of 28 to $35^{\circ} \mathrm{C}$, and subsequent penetration into the roots. The pathogen usually grows through the xylem and colonizes vascular tissues. On strawberry, plant mortality owing to infections by $M$. phaseolina is more related to elevated soil temperature than moisture stress (Zveibil et al. 2012). In Florida, these higher temperature regimes, which favor infection, occur during late fall after planting and at the end of the season in March and April when air and soil temperatures seasonally increase.

M. phaseolina can cause a range of symptoms on its hosts from restricted spindle-shaped lesions to extended lesions resulting in the

${ }^{\dagger}$ Corresponding author: Natalia A. Peres; E-mail: nperes@ufl.edu

Funding: This work was partially supported by the Florida Strawberry Research and Education Foundation (FSREF) and the European Social Fund (FEDER).

Accepted for publication 13 May 2018.

() 2018 The American Phytopathological Society wilting of the plant (Kaur et al. 2012). In strawberry, symptoms are usually observed along the vascular rings and are characterized by dark brown necrotic areas in the crowns, leading to wilting and death of older leaves and eventual collapse and death of plants (Avilés et al. 2008; Mertely et al. 2005). M. phaseolina might cause charcoal rot at low inoculum densities, especially in highly susceptible hosts, such as strawberry (Sánchez et al. 2013; Zhang et al. 2016; Zveibil and Freeman 2005).

Management of $M$. phaseolina is usually achieved with a combination of cultural practices and chemical methods. Farmyard manure, ground poultry litter, solarization, natural heating of irrigated soil, and biofumigation with residues of Brassicaceae were shown to be effective in reducing M. phaseolina inoculum in the field (Chamorro et al. 2015; Mazzola 2011; Pratt 2006; Zveibil et al. 2012). In plasticulture production, preplant fumigation of soil is the most common method to reduce inoculum levels and control soilborne diseases, weeds, and nematodes on horticultural crops, such as tomatoes, strawberries, peppers, cucurbits, ornamentals, and so on (Boyd et al. 2017; Fennimore et al. 2013; McGovern 2015; Short et al. 2015). MeBr, historically used as a soil fumigant before establishment of the crops for over 40 years, is highly effective in controlling pests and plant pathogens, including $M$. phaseolina, and was the main product used on horticultural crops to manage soil diseases (Duniway 2002). California and Florida, in the United States, were the states with the highest use of $\mathrm{MeBr}$ in soil (Ristaino and Thomas 1997). MeBr is a broadspectrum soil fumigant, acutely toxic, highly volatile to penetrate soils for some distance from the point of application, and effective for soil disinfestation (Duniway 2002). However, $\mathrm{MeBr}$ was recognized as a stratospheric ozone-depleting agent and was ultimately banned from agricultural use in 2015 in both developed and underdeveloped countries (Duniway 2002; Guthman 2016; U.S. EPA n.d.). Since the phase out of $\mathrm{MeBr}$, new outbreaks and increased incidence of $M$. phaseolina infections and emergence of diseases caused by Phytophthora spp., Verticillium spp., and Fusarium spp. in strawberries have been reported in several strawberry production regions worldwide (Chellemi et al. 2016; Koike et al. 2016; McGovern 2015; Mertely et al. 2005; Pastrana et al. 2014). Moreover, recent reports of M. phaseolina affecting strawberries in new locations as well as new crops have been showing up around the world (Sánchez et al. 2013; Sun et al. 2015; Zhang et al. 2016).

Owing to the long-term survival of M. phaseolina sclerotia in soil, the loss of $\mathrm{MeBr}$ as a pest control tool to mitigate plant growth and yield impacts of $M$. phaseolina in plasticulture horticultural crops, including strawberry, means that growers need as efficient chemical 
and nonchemical alternatives to manage soilborne pathogens. Despite the transition to alternative broad-spectrum fumigants (e.g., 1,3dichloropropene/chloropicrin, chloropicrin, metam sodium, and metam potassium), these products are not always as effective as $\mathrm{MeBr}$ in managing soil populations of $M$. phaseolina, especially because of the limited diffusion to the sides of the beds (Chamorro et al. 2016). Therefore, different methods of application, formulations, and product combinations still need to be identified and evaluated to improve disease management. Soil fumigants are usually applied via shank or drip, depending on product formulation, before or after bed formation (Chamorro et al. 2016; Noling 2015). Alternative fumigants have not only been tested for the control of $M$. phaseolina but also for other pathogens, nematodes, and weeds in several plasticulture crops (Boyd et al. 2017; McGovern 2015; Noling et al. 2015; Short et al. 2015).

Among the alternative fumigants currently registered for use in U.S. strawberry, Dominus (Isagro, Morrisville, NC) is a synthetic biofumigant composed of $96.3 \%$ allyl isothiocyanate (AITC) as the active ingredient (Isagro 2013, 2017a). The U.S. Environmental Protection Agency classifies the product as a broad-spectrum biofumigant and biopesticide (U.S. EPA n.d.). AITC is a naturally occurring biofumigant compound derived from mustard oil present in Brassica species that has been synthesized for use in both conventional and organic production; however, it is still under review by the National Organic Program (Isagro 2017b). In Florida, Dominus is currently registered for use on all food and nonfood crops, including turf and strawberries. It is currently labeled as a multispectral fumigant for preplant application or crop termination treatment that can be applied via drip irrigation or via in-row shank treatment (Noling 2015). Performance of commercial formulations of AITC for the control of nematodes, soilborne pathogens, and weeds is still under assessment in Florida (Noling 2015), and there are few reports on its efficacy to manage soilborne pests. Most of the recent research documents report the effectiveness of AITC soil fumigation for control of weeds and nematodes in plasticulture crops (Devkota and Norsworthy 2014; Ntalli and Caboni 2017). However, there are no reports about the effect of commercial formulations of AITC for management of $M$. phaseolina.

Therefore, the main objective of this study was to evaluate the performance of formulations of AITC in reducing inoculum of $M$. phaseolina in the soil. Our objectives were (i) to assess the efficacy of different rates, formulations, fumigant combinations, and application methods, (ii) to compare the efficacy of formulations of AITC with other standard fumigants used in Florida, and (iii) to evaluate the spatial distribution of the fumigants within the plastic-covered beds using fungicidal activity as a bioassay for controlling M. phaseolina inoculum in the soil.

\section{Materials and Methods}

Experimental design and treatment application. Six experiments were conducted at the Gulf Coast Research and Education Center (GCREC) in Balm, FL, and two at the Florida Strawberry Growers Association (FSGA) research facility in Dover, FL, during the fall of 2014 and 2015. The efficacy of formulations of AITC was compared with the standard treatments for Florida strawberry growers such as $\mathrm{MeBr}$ plus chloropicrin at ratios of 67/33 and 50/ 50 (MeBr67 and MeBr50, respectively), two treatments of 1,3dichloropropene/chloropicrin at ratios of 63/35 and 39/60 (Telone C35, Dow Agrosciences, Indianapolis, IN, and Pic-Clor60, Trical, Hollister, CA, respectively), and metam potassium (K-pam Amvac, Los Angeles, CA). All treatments were compared with a nontreated control (NTC). AITC was also tested in mixture with an adjuvant, Atlox (copolymers of acrylic acid and polyalkylene oxides), and in combination with chloropicrin (AITC+Pic). The description of the treatments is in Table 1.

For the trials in Dover, treatments were applied either by shank injection on 8 September 2014 and 10 September 2015 or by drip injection into the irrigation stream on 3 October 2014 and 5 October 2015. The soil type at the Dover site is a Zolfo fine sand (sandy, siliceous, hyperthermic Oxyaquic Alorthod). All of the shank-applied fumigants were soil injected via two shanks $35 \mathrm{~cm}$ apart and $25 \mathrm{~cm}$ deep into the bed using nitrogen as propellant through a two-row fumigation rig. Beds were then immediately formed and sealed using a two-row bed press. Polyethylene mulch (VaporSafe TIF, Raven Industries, Berry Plastics, Evansville, IN) and/or low-density polyethylene mulch were immediately installed over the raised plant bed using a speed roller, with each bed receiving one Netafim drip tape centrally buried $2.5 \mathrm{~cm}$ deep and delivering $1,360 \mathrm{ml}$ per emitter per hour on $30-\mathrm{cm}$ spacing. All drip treatments were made via drip tape over a 3 -h injection period with a $15 \mathrm{~min}$ charge and $30 \mathrm{~min}$ flush time. All drip fumigant injections derived from nitrogen-pressurized fumigant cylinders and using changes in cylinder weight and/or were metered into the irrigation stream using a low-flow 7440 series King flow meter $(20 \mathrm{LPH}$, King Instrument Company, Garden Grove, CA). All drip fumigants were injected into pressure-regulated irrigation water directly upstream of two 2.5-cm polypropylene line strainers (mixing chambers) with 100 stainless screen mesh before exiting the injection manifold and into the drip tape lines for the appropriate plant rows. The beds were $73.1 \mathrm{~m}$ long, $76.2 \mathrm{~cm}$ wide, $30.5 \mathrm{~cm}$ high at the center, and $25 \mathrm{~cm}$ high at the edges. The distances between bed centers were $1.2 \mathrm{~m}$. Each plot consisted of two adjacent beds.

For the trials in Balm, treatments were applied by either shank injection on 4 August 2014 and 13 August 2015 or by drip injection into the irrigation stream on 21 August 2014 and 20 and 31 August 2015. The soil type at the Balm site is a Myakka fine sand (siliceous, hyperthermic Oxyaquic Alorthod) with $\mathrm{pH}$ of 6.1 to 6.8 and organic matter content of 0.9 to $1.5 \%$. For shank-injection fumigant trials, a prebed was initially pulled and shaped using a three-row bed press (Kennco Manufacturing, Ruskin, FL) followed by soil application of fumigants through three swept back shanks, spaced $23 \mathrm{~cm}$ apart and $20.5 \mathrm{~cm}$ deep into the bed using nitrogen as a propellant with a single-row fumigation rig (Kennco Manufacturing). Beds were then immediately sealed using a single-row bed press and then covered with a virtually impermeable film (Blockade, Berry Plastics, Evansville, IN) with two drip tapes offset $15 \mathrm{~cm}$ from the bed center and buried $2.5 \mathrm{~cm}$ deep capable of delivering $950 \mathrm{ml}$ per emitter per hour on 30-cm spacing (Netafim, Fresno, CA).

Beds were prepared for drip injection treatments in a similar fashion, except beds were pressed twice with the three-row bed press prior to applying drip tape and film. All drip treatments were continuously injected through the two drip tapes over a 2-h injection period with a 15-min charge and 15-min flush time using a 5.7-liters/min electric diaphragm pump to deliver fumigant treatments directly to each plot from a 132-liter recirculating tank. A total of $3 \mathrm{~cm} / \mathrm{ha}$ of

Table 1. Treatments applied to soil by shank or drip injection in fields in Balm and Dover, FL, during the fall of 2014 and 2015

\begin{tabular}{|c|c|c|}
\hline Treatments & Active ingredient & $\operatorname{Acronym}^{\mathrm{z}}$ \\
\hline Dominus & $\begin{array}{l}\text { Allyl isothiocyanate (AITC) }(99 \%)+ \\
\text { Tween }\end{array}$ & Dominus \\
\hline AITC+Atlox & Allyl isothiocyanate + Atlox & AITC+Atlox \\
\hline AITC & Allyl isothiocyanate $(100 \%)$ & AITC \\
\hline AITC+Pic & $\begin{array}{l}\text { Allyl isothiocyanate }+ \text { chloropicrin } \\
(67 / 33)\end{array}$ & $\mathrm{AITC}+\mathrm{Pic}$ \\
\hline AITC+Pic-Clor 60 & $\begin{array}{l}\text { Allyl isothiocyanate + chloropicrin/ } \\
\text { 1,3-dichloropropene }(50 / 50)\end{array}$ & AITC+Pic60 \\
\hline AITC+Pic+1,3-D & $\begin{array}{l}\text { Allyl isothiocyanate }+ \text { chloropicrin }+ \\
\text { 1,3-dichloropropene }(33 / 33 / 33)\end{array}$ & $\begin{array}{l}\text { AITC+Pic+ } \\
1,3-\mathrm{D}\end{array}$ \\
\hline MeBr67 & Methyl bromide + chloropicrin $(67 / 33)$ & MeBr67 \\
\hline $\mathrm{MeBr} 50$ & Methyl bromide + chloropicrin $(50 / 50)$ & MeBr50 \\
\hline Telone C35 & $\begin{array}{l}\text { 1,3-Dichloropropene/chloropicrin } \\
(63 / 35)\end{array}$ & C35 \\
\hline Inline & $\begin{array}{l}\text { 1,3-Dichloropropene/chloropicrin } \\
(61 / 33)\end{array}$ & Inline \\
\hline Metam potassium & Potassium $N$-methyldithiocarbamate & $\begin{array}{l}\text { Metam } \\
\text { potassium }\end{array}$ \\
\hline Pic-Clor 60 & $\begin{array}{l}\text { 1,3-Dichloropropene/chloropicrin } \\
(39 / 60)\end{array}$ & Pic60 \\
\hline NTC & Nontreated control & NTC \\
\hline
\end{tabular}

${ }^{\mathrm{z}}$ Used in the text. 
water was applied to each plot at $69 \mathrm{kPa}$. Individual plots were prepared along $97.5-\mathrm{m}$-long beds, which were $76 \mathrm{~cm}$ wide at the bed top, $86 \mathrm{~cm}$ wide at the bed bottom, $23 \mathrm{~cm}$ high at the bed center, and $20 \mathrm{~cm}$ high at the bed edges. The distances between bed centers were $1.5 \mathrm{~m}$. Each plot consisted of 23-m length along a single prepared bed for shank and drip injected treatments.

Production of $M$. phaseolina inoculum and placement in the beds. Three pathogenic M. phaseolina isolates from Florida strawberry fields were revived from our culture collection and transferred to potato dextrose agar plates for the production of sclerotia, and inoculum was prepared on corn cob pieces (Kay-kob pet litter, KayTee, Chilton, WI) infested with $M$. phaseolina. Inoculum was prepared following the methods of Chamorro et al. (2016). M. phaseolina bags were buried in plastic-mulched (one or two per bed, depth, and location) raised beds at 7.6 and $20.3 \mathrm{~cm}$ deep in the center of the bed. Additional sample bags were buried at $7.6 \mathrm{~cm}$ deep on one side of the bed at $25 \mathrm{~cm}$ from the center of the bed. M. phaseolina inoculum was buried in the beds 1 day prior to the application of drip treatments and 5 to 15 min after shank treatments were applied. Bags were collected prior to planting, approximately 1 month after treatment application. Samples were then air dried and stored in paper bags at room temperature for up to 15 days before processing.

Quantification of viable $M$. phaseolina population in bag samples. M. phaseolina populations were calculated as colony forming units per bag (CFU/bag) following the method of Chamorro et al. (2016).

Statistical analysis. A split-plot analysis was conducted considering M. phaseolina inoculum burial placement (depth and location) as the whole plot and fumigant treatments as the split plot. M. phaseolina $\mathrm{CFU} / \mathrm{bag}$ data were transformed $(\mathrm{CFU}+0.5)$ prior to analysis because of the high number of plates with zero colonies. Individual

Table 2. Type III test of fixed effects of the eight experiments conducted during the fall of 2014 and 2015 with the significance of the effects tested

\begin{tabular}{|c|c|c|c|c|c|}
\hline Location $^{x}$ & Year & $\begin{array}{l}\text { Application } \\
\text { method }\end{array}$ & Effect $^{y}$ & $F$ value & $\operatorname{Pr}>F^{\mathbf{z}}$ \\
\hline \multirow[t]{18}{*}{ GCREC } & 2014 & $\begin{array}{l}\text { Shank, single/ } \\
\text { dual port }\end{array}$ & Local & 10.82 & 0.0102 \\
\hline & & & Treatment & 37.45 & $<0.0001$ \\
\hline & & & Local $\times$ treatment & 1.98 & 0.0441 \\
\hline & & Drip, two tapes & Local & 44.53 & 0.0003 \\
\hline & & & Treatment & 43.02 & $<0.0001$ \\
\hline & & & Local $\times$ treatment & 4.49 & $<0.0001$ \\
\hline & 2015 & Drip, two tapes & Local & 8.77 & 0.0166 \\
\hline & & & Treatment & 41.04 & $<0.0001$ \\
\hline & & & Local $\times$ treatment & 1.99 & 0.0569 \\
\hline & & Drip, one tape & Local & 3.96 & 0.0801 \\
\hline & & & Treatment & 20.56 & $<0.0001$ \\
\hline & & & Local $\times$ treatment & 1.13 & 0.3716 \\
\hline & & $\begin{array}{l}\text { Shank, single } \\
\text { port }\end{array}$ & Local & 1.3 & 0.3384 \\
\hline & & & Treatment & 59.77 & $<0.0001$ \\
\hline & & & Local $\times$ treatment & 0.44 & 0.9174 \\
\hline & & $\begin{array}{l}\text { Shank, dual } \\
\text { port }\end{array}$ & Local & 0.23 & 0.7994 \\
\hline & & & Treatment & 68.76 & $<0.0001$ \\
\hline & & & Local $\times$ treatment & 1.18 & 0.3049 \\
\hline \multirow[t]{6}{*}{ FSGA } & 2014 & Shank/drip & Local & 14.88 & 0.0047 \\
\hline & & & Treatment & 29.12 & $<0.0001$ \\
\hline & & & Local $\times$ treatment & 4.84 & $<0.0001$ \\
\hline & 2015 & Shank/drip & Local & 4.6 & 0.0616 \\
\hline & & & Treatment & 20.77 & $<0.0001$ \\
\hline & & & Local $\times$ treatment & 4.07 & $<0.0001$ \\
\hline
\end{tabular}

${ }^{x}$ GCREC $=$ Gulf Coast Research and Education Center (Balm, FL), and FSGA = Florida Strawberry Growers Association (Dover, FL).

${ }^{y}$ The effects of local (position of the inoculum in the bed), treatment (fumigant), and the interaction between those were evaluated in a split-plot design, with burial local considered as the whole plot and the fumigant treatments as the split plot.

${ }^{\mathrm{z}}$ Probability of a greater $F$ value. $P$ values $<0.05$ were considered significant $(\alpha=5 \%)$. years (2014 and 2015), application methods (shank and drip), and inoculum burial placement ( 7.6 and $20.3 \mathrm{~cm}$ deep on the center of the bed, and $7.6 \mathrm{~cm}$ deep on the shoulder of the bed) were analyzed independently to obtain additional information on the treatment effect in each situation and replication. Statistical analysis was performed using PROC GLIMMIX in SAS version 9.4 (SAS Institute, Cary, NC) with the functions dist $=$ Poisson and link $=\log$ to fit the data into a Poisson distribution. To check the significance of the treatments $(P \leq 0.05)$ in each scenario cited above, generalized linear mixed models for $M$. phaseolina $\mathrm{CFU} / \mathrm{bag}$ were fit, with treatment as a fixed variable and with repetition and interactions between repetition and whole and split plot as random variables to account for single-unit (plots) variance. When models were significant, means were compared using Fisher's least significant difference at $P \leq$ 0.05 . When the interaction between burial location and fumigants was significant, the slice function was used to check in which treatments the burial location was significant.

\section{Results}

Fumigant treatment effects were highly significant on all of the factors evaluated $(P<0.0001)$ (Table 2$)$. All the AITC treatments were effective in reducing $M$. phaseolina inoculum located at 7.6 and $20.3 \mathrm{~cm}$ deep in the center of the bed regardless of application method, rate, formulation, and fumigant combinations. However, treatments showed inconsistent results reducing M. phaseolina population on the sides of the bed.

Effect of treatments on M. phaseolina inoculum in 2014. In the experiment conducted at the GCREC, fumigants were drip injected through two drip tapes. Metam potassium, Inline, and all AITC treatments statistically reduced $M$. phaseolina inoculum at both depths at the center of the beds compared with the NTC. However, Inline was not as effective as the other treatments. Metam potassium, high and medium doses of AITC+Atlox, and AITC+Pic were the only treatments that reduced $M$. phaseolina inoculum at the side of the beds $(7.6 \mathrm{~cm})$ using two drip tapes per bed (Table 3). In another experiment in which treatments were applied by shank injection, Pic60 was the only treatment that did not reduce $M$. phaseolina inoculum at either bed depth evaluated. Moreover, despite the effectiveness of Dominus applied through single-port shanks to reduce inoculum at both depths in the center of the bed, it was not effective at the side of the beds $(7.6 \mathrm{~cm})$ (Table 4). In the experiment carried out at FSGA, all the treatments were effective in reducing $M$. phaseolina inoculum in the center of the bed regardless of bed application method. However, MeBr67, MeBr50, C35, and Pic60 were the only treatments that statistically reduced inoculum on the side of the bed relative to the NTC (Table 5).

Effect of treatments on M. phaseolina inoculum in 2015. In the two experiments located at the GCREC in which fumigants were applied by either one or two drip irrigation tapes, Pic60 and all the AITC treatments statistically reduced $M$. phaseolina inoculum located in the center of the bed (Tables 6 and 7) when compared with the NTC. Inoculum located on the side of the bed was not statistically reduced by Dominus applied at the low rate with one tape (Table 6) or by AITC+Pic delivered through two tapes (Table 7) compared with the NTC. For trials in which bed treatments were shank injected using shanks with either one or two ports, all the fumigants tested reduced M. phaseolina inoculum at both depths in the center and on the side of the bed compared with the NTC. However, all the AITC treatments performed significantly better than Pic60 at all bed locations evaluated (Tables 8 and 9). In the experiment located at FSGA, MeBr67 and MeBr50 were the only treatments that statistically reduced $M$. phaseolina inoculum at the three bed locations evaluated compared with the NTC. Dominus, metam potassium, and both rates of AITC+Pic effectively reduced inoculum densities of $M$. phaseolina recovered from both depths in the center of the bed. Pic60 had no effect on inoculum population at any bed location evaluated, whereas C35 decreased M. phaseolina incidence only at the $20.3 \mathrm{~cm}$ depth (Table 10).

\section{Discussion}

Proper soil fumigation in plasticulture production systems is crucial to achieve management of soilborne pathogens, weeds, and 
nematodes that affect crop yield. Since MeBr was phased out in 2013, diseases caused by pathogens such as M. phaseolina have become more prevalent, and growers now must rely on the use of less effective alternative soil fumigants to reduce inoculum levels and control diseases (Koike et al. 2016; Mertely et al. 2005; Zveibil et al. 2012). In fact, studies with soil fumigants to reduce soil populations of $M$. phaseolina have been reported worldwide (Chamorro et al. 2015, 2016; Hartz et al. 1987; Watanabe et al. 1970).
In our study, formulations of the biofumigant AITC were compared with the most commonly used soil fumigants in plasticulture production to reduce artificial inoculum of $M$. phaseolina in bags placed in different depths and bed locations in plastic-covered beds. To our knowledge, this is the first report of the use of formulations of the biofumigant AITC for controlling or reducing inoculum levels of M. phaseolina in soils, whereas its effectiveness against weeds and nematodes has already been studied (Devkota and Norsworthy 2014; Ntalli and Caboni 2017).

Table 3. Treatments applied to soil by drip injection with two tapes in a field at the Gulf Coast Research and Education Center in Balm, FL, in 2014 and their effects on inoculum of Macrophomina phaseolina at different bed locations

\begin{tabular}{|c|c|c|c|c|c|}
\hline \multirow[b]{2}{*}{ Treatments $^{\mathrm{w}}$} & \multirow[b]{2}{*}{ Rate } & \multicolumn{3}{|c|}{ M. phaseolina $(\mathrm{CFU} / \mathrm{bag})^{\mathrm{x}}$} & \multirow[b]{2}{*}{$\operatorname{Pr}>F^{y}$} \\
\hline & & $7.6 \mathrm{~cm}$, center & $20.3 \mathrm{~cm}$, center & $7.6 \mathrm{~cm}$, side & \\
\hline Dominus & 280.2 liters/ha & $2.2 \mathrm{c}$ & $4.6 \mathrm{c}$ & $2,487 \mathrm{a}$ & $<0.0001$ \\
\hline AITC+Atlox & 280.2 liters/ha & $1.7 \mathrm{c}$ & $4.4 \mathrm{c}$ & $10.9 \mathrm{~b}$ & 0.1668 \\
\hline AITC+Atlox & 233.5 liters/ha & $1.0 \mathrm{c}$ & $1.5 \mathrm{c}$ & $37.8 \mathrm{~b}$ & 0.0007 \\
\hline AITC+Atlox & 186.8 liters/ha & $2.7 \mathrm{c}$ & $0.9 \mathrm{c}$ & $75.6 \mathrm{~b}$ & 0.0001 \\
\hline AITC+Atlox & 140.1 liters/ha & $1.0 \mathrm{c}$ & $3.7 \mathrm{c}$ & $1,151.8 \mathrm{a}$ & $<0.0001$ \\
\hline AITC+Pic & $252.0 \mathrm{~kg} / \mathrm{ha}$ & $2.2 \mathrm{c}$ & $3.7 \mathrm{c}$ & $46.0 \mathrm{~b}$ & 0.0034 \\
\hline Inline & 280.2 liters/ha & $293.4 \mathrm{~b}$ & $65.6 \mathrm{~b}$ & $5,369.7$ a & $<0.0001$ \\
\hline Metam potassium & 560.4 liters/ha & $2.0 \mathrm{c}$ & $1.4 \mathrm{c}$ & $33.6 \mathrm{~b}$ & 0.0029 \\
\hline NTC & $\ldots$ & $2,554.5 \mathrm{a}$ & $6,449.6 \mathrm{a}$ & $2,690.6 \mathrm{a}$ & 0.5247 \\
\hline $\operatorname{Pr}>F^{\mathrm{z}}$ & & $<0.0001$ & $<0.0001$ & $<0.0001$ & $\ldots$ \\
\hline
\end{tabular}

w Treatment abbreviations defined in Table 1.

${ }^{x}$ M. phaseolina colony-forming units per bag (CFU/bag). Treatments followed by the same letter within a column are not significantly different according to Fisher's protected LSD test $(\alpha=0.05)$.

y Probability associated with test of effect slices for local $\times$ treatment interaction, sliced by treatment.

${ }^{z}$ Probability of a greater $F$ value. Probability associated with type III test of fixed effects for treatments within each location.

Table 4. Treatments applied to soil by shank injection with three or four knifes, single- or dual-port rig, in a field at the Gulf Coast Research and Education Center in Balm, FL, in 2014 and their effects on inoculum of Macrophomina phaseolina at different bed locations

\begin{tabular}{|c|c|c|c|c|c|c|}
\hline \multirow[b]{2}{*}{ Treatments $^{\mathrm{w}}$} & \multirow[b]{2}{*}{ Rate } & \multirow[b]{2}{*}{ Application (knives; depth [cm]) } & \multicolumn{3}{|c|}{ M. phaseolina $(\mathrm{CFU} / \mathrm{bag})^{\mathrm{x}}$} & \multirow[b]{2}{*}{$\operatorname{Pr}>F^{y}$} \\
\hline & & & $7.6 \mathrm{~cm}$, center & $20.3 \mathrm{~cm}$, center & $7.6 \mathrm{~cm}$, side & \\
\hline AITC & $280.2 \mathrm{~kg} / \mathrm{ha}$ & $3 ; 7.6$ and 20.3 & $5.9 \mathrm{bc}$ & $3.6 \mathrm{~b}$ & $9.4 \mathrm{c}$ & 0.6757 \\
\hline AITC & $280.2 \mathrm{~kg} / \mathrm{ha}$ & $4 ; 7.6$ and 20.3 & $1.0 \mathrm{c}$ & $1.4 \mathrm{~b}$ & $4.3 \mathrm{c}$ & 0.4429 \\
\hline $\mathrm{AITC}+\mathrm{Pic}$ & $252 \mathrm{~kg} / \mathrm{ha}$ & $4 ; 7.6$ and 20.3 & $1.4 \mathrm{bc}$ & $2.6 \mathrm{~b}$ & $29.3 \mathrm{bc}$ & 0.0364 \\
\hline AITC & $280.2 \mathrm{~kg} / \mathrm{ha}$ & $4 ; 20.3$ & $10.0 \mathrm{~b}$ & $0.9 \mathrm{~b}$ & $533.5 \mathrm{ab}$ & $<0.0001$ \\
\hline $\mathrm{AITC}+\mathrm{Pic}$ & $252 \mathrm{~kg} / \mathrm{ha}$ & $4 ; 20.3$ & $0.9 \mathrm{c}$ & $5.9 \mathrm{~b}$ & $69.8 \mathrm{bc}$ & 0.006 \\
\hline Pic60 & $336 \mathrm{~kg} / \mathrm{ha}$ & $4 ; 20.3$ & $2,318.2 \mathrm{a}$ & $2,796.7 \mathrm{a}$ & $2,917.9 \mathrm{a}$ & 0.9793 \\
\hline NTC & $\ldots$ & $\ldots$ & $3,259.7 \mathrm{a}$ & $2,044.9 \mathrm{a}$ & $3,006.9 \mathrm{a}$ & 0.9171 \\
\hline $\operatorname{Pr}>F^{\mathrm{z}}$ & & & $<0.0001$ & $<0.0001$ & 0.0006 & $\ldots$ \\
\hline
\end{tabular}

w Treatment abbreviations defined in Table 1.

${ }^{x}$ M. phaseolina colony-forming units per bag (CFU/bag). Treatments followed by the same letter within a column are not significantly different according to Fisher's protected LSD test $(\alpha=0.05)$.

y Probability associated with test of effect slices for local $\times$ treatment interaction, sliced by treatment.

z Probability of a greater $F$ value. Probability associated with type III test of fixed effects for treatments within each location.

Table 5. Treatments applied to soil by shank injection with two-knife single-port rig or drip (one tape) in a field at the Florida Strawberry Growers Association facility in Dover, FL, in 2014 and their effects on inoculum of Macrophomina phaseolina at different bed locations

\begin{tabular}{|c|c|c|c|c|c|}
\hline \multirow[b]{2}{*}{ Treatments $^{\mathrm{w}}$} & \multirow[b]{2}{*}{ Rate } & \multicolumn{3}{|c|}{ M. phaseolina $(\mathrm{CFU} / \mathrm{bag})^{\mathrm{x}}$} & \multirow[b]{2}{*}{$\operatorname{Pr}>F^{y}$} \\
\hline & & $7.6 \mathrm{~cm}$, center & $20.3 \mathrm{~cm}$, center & $7.6 \mathrm{~cm}$, side & \\
\hline MeBr67 & $392 \mathrm{~kg} / \mathrm{ha}$ & $2.6 \mathrm{c}$ & $1.8 \mathrm{~cd}$ & $4.9 \mathrm{~d}$ & 0.6506 \\
\hline MeBr50 & $358.4 \mathrm{~kg} / \mathrm{ha}$ & $3.1 \mathrm{c}$ & $1.7 \mathrm{~cd}$ & $1.3 \mathrm{~d}$ & 0.7408 \\
\hline C35 & 280.2 liters/ha & $1.6 \mathrm{c}$ & $0.8 \mathrm{~d}$ & $21.4 \mathrm{~cd}$ & 0.0100 \\
\hline Pic60 & $336 \mathrm{~kg} / \mathrm{ha}$ & $468.6 \mathrm{~b}$ & $119.4 \mathrm{~b}$ & $29.7 \mathrm{~cd}$ & 0.0444 \\
\hline Metam potassium & 560.4 liters $/ \mathrm{ha}$ & $5.9 \mathrm{c}$ & $2.7 \mathrm{~cd}$ & $111.9 \mathrm{bc}$ & 0.0024 \\
\hline Dominus & 145.7 liters/ha & $3.2 \mathrm{c}$ & $10.1 \mathrm{c}$ & $3,115.2 \mathrm{a}$ & $<0.0001$ \\
\hline $\mathrm{AITC}+\mathrm{Pic}$ & $227.4 \mathrm{~kg} / \mathrm{ha}$ & $3.6 \mathrm{c}$ & $8.3 \mathrm{c}$ & $347.9 \mathrm{abc}$ & 0.0001 \\
\hline NTC & $\ldots$ & $2,889.3 \mathrm{a}$ & $2,309.8 \mathrm{a}$ & $2,127.3 \mathrm{ab}$ & 0.9568 \\
\hline $\operatorname{Pr}>F^{z}$ & & $<0.0001$ & $<0.0001$ & 0.0003 & $\ldots$ \\
\hline
\end{tabular}

${ }^{\mathrm{w}}$ Treatment abbreviations defined in Table 1. Metam potassium, Dominus, and AITC+Pic were applied through drip tape. The remainder of the treatments were applied via shank injection.

x M. phaseolina colony-forming units per bag (CFU/bag). Treatments followed by the same letter within a column are not significantly different according to Fisher's protected LSD test $(\alpha=0.05)$.

y Probability associated with test of effect slices for local $\times$ treatment interaction, sliced by treatment.

${ }^{\text {z }}$ Probability of a greater $F$ value. Probability associated with type III test of fixed effects for treatments within each location. 
Compared with $\mathrm{MeBr} / \mathrm{chloropicrin}$, all of the currently registered soil fumigants possess significantly lower vapor pressures and higher boiling points, which seriously delay volatilization and limit radial diffusion through soil (Porter et al. 2004). Commercial formulations of AITC, like other fumigants, have lower vapor pressures and higher boiling points than $\mathrm{MeBr}$, and their efficacy in the control of soilborne pests is more dependent on the method of application and soil type (Ajwa et al. 2002; Isagro 2013; McGovern et al. 1998). For this reason, different application methods, such as single- or dual-port shanks and drip injection through one or two tapes, and different formulations of AITC were tested in our trials to evaluate the spatial distribution of the fumigants within the beds using their fungicidal

Table 6. Treatments applied to soil by drip irrigation with one tape in at the Gulf Coast Research and Education Center in Balm, FL, in 2015 and their effects on inoculum of Macrophomina phaseolina at different bed locations

\begin{tabular}{lcccc}
\hline & & \multicolumn{3}{c}{ M. phaseolina $(\mathbf{C F U} / \mathbf{b a g})^{\mathbf{y}}$} \\
\cline { 3 - 5 } & Rate & $\begin{array}{c}\mathbf{7 . 6} \mathbf{~ c m}, \\
\text { center }\end{array}$ & $\begin{array}{c}\mathbf{2 0 . 3} \mathbf{~ c m}, \\
\text { center }\end{array}$ & $\begin{array}{c}\mathbf{7 . 6} \mathbf{~ c m}, \\
\text { side }\end{array}$ \\
\hline Treatments & \\
\hline Dominus & 168.1 liters/ha & $24.5 \mathrm{~b}$ & $3.6 \mathrm{~b}$ & $133.1 \mathrm{ab}$ \\
AITC+Pic & 168.1 liters/ha & $10.5 \mathrm{~b}$ & $1.1 \mathrm{~b}$ & $7.1 \mathrm{bc}$ \\
Dominus & 280.2 liters/ha & $3.3 \mathrm{~b}$ & $1.3 \mathrm{~b}$ & $25.5 \mathrm{bc}$ \\
AITC+Pic & 280.2 liters/ha & $2.3 \mathrm{~b}$ & $4.3 \mathrm{~b}$ & $2.3 \mathrm{c}$ \\
NTC & $\ldots$ & $1,102.4 \mathrm{a}$ & $1,371.9 \mathrm{a}$ & $1,608.2 \mathrm{a}$ \\
$\operatorname{Pr}>F^{\mathrm{z}}$ & & 0.0112 & $<0.0001$ & 0.0166 \\
\hline
\end{tabular}

$\mathrm{x}$ Treatment abbreviations defined in Table 1 .

${ }^{\mathrm{y}}$ M. phaseolina colony-forming units per bag (CFU/bag). Treatments followed by the same letter within a column are not significantly different according to Fisher's protected LSD test $(\alpha=0.05)$.

${ }^{z}$ Probability of a greater $F$ value. Probability associated with type III test of fixed effects. activity as a bioassay for controlling $M$. phaseolina inoculum in the soil.

The different AITC formulations and rates were generally effective in controlling $M$. phaseolina inoculum in the center of the bed In some trials, these products were more effective than the standard fumigants, such as chloropicrin and 1,3-dichloropropene with chloropicrin, and as effective as $\mathrm{MeBr}$. However, inconsistent results on the survival of $M$. phaseolina inoculum on the side of the beds were observed. This could be explained by the limited lateral movement of liquid fumigant product in irrigation water across the bed composed of highly permeable fine sandy soil, and differences in infiltration and permeability (Duerksen and Ajwa 2004; Spurlock et al. 2013). For instance, owing to low volatility and poor mobility through the bed profile, AITC treatments applied by two drip tapes were usually more effective in reducing pathogen inoculum than injection through one drip tape. Moreover, application of AITC treatments by shank injection with a dual-port rig might improve the performance of the product in controlling $M$. phaseolina population on the sides of the beds.

Although drip fumigation has become more common owing to flexibility in application, the possibility to reuse the plasticmulched beds for additional crops, and reduction in the potential for worker exposure (Ajwa et al. 2002; Noling et al. 2011), AITC treatments applied via shank were more effective in reducing $M$. phaseolina inoculum on the side of the beds than through drip tapes in our studies. Similar results were observed in nut tree (Prunus spp.) nursery fields, where shank-injected fumigants provided better nematode control than products applied through drip lines (Schneider et al. 2009). For 1,3-dicholopropene, however, similar distribution through the bed profiles were obtained when the fumigant was applied with either drip irrigation or shank injection (Wang and Yates 1999). Moreover, 1,3-dichlopropene is more volatile than AITC, with boiling point of $108^{\circ} \mathrm{C}$ compared with $150^{\circ} \mathrm{C}$ for AITC (O’Neil 2013). Drip applications usually place the chemical close

Table 7. Treatments applied to soil by drip irrigation with two tapes in a field at the Gulf Coast Research and Education Center in Balm, FL, in 2015 and their effects on inoculum of Macrophomina phaseolina at different bed locations

\begin{tabular}{|c|c|c|c|c|}
\hline \multirow[b]{2}{*}{ Treatments $^{\mathrm{x}}$} & \multirow[b]{2}{*}{ Rate } & \multicolumn{3}{|c|}{ M. phaseolina $(\mathrm{CFU} / \mathrm{bag})^{\mathrm{y}}$} \\
\hline & & $7.6 \mathrm{~cm}$, center & $20.3 \mathrm{~cm}$, center & $7.6 \mathrm{~cm}$, side \\
\hline Dominus & 280.2 liters/ha & $12.8 \mathrm{~b}$ & $3.2 \mathrm{~b}$ & $65.4 \mathrm{~b}$ \\
\hline $\mathrm{AITC}+\mathrm{Pic}$ & 392 liters/ha & $5.9 \mathrm{bc}$ & $0.9 \mathrm{~b}$ & $120.3 \mathrm{ab}$ \\
\hline AITC+Pic+1,3-D & 392 liters/ha & $1.6 \mathrm{bc}$ & $0.9 \mathrm{~b}$ & $3.3 \mathrm{c}$ \\
\hline AITC+Pic60 & 392 liters/ha & $1.8 \mathrm{bc}$ & $0.5 \mathrm{~b}$ & $0.7 \mathrm{c}$ \\
\hline Pic60 & $336 \mathrm{~kg} / \mathrm{ha}$ & $0.7 \mathrm{c}$ & $0.5 \mathrm{~b}$ & $0.9 \mathrm{c}$ \\
\hline NTC & $\ldots$ & $370.6 \mathrm{a}$ & $613.8 \mathrm{a}$ & $874.6 \mathrm{a}$ \\
\hline $\operatorname{Pr}>F^{z}$ & & 0.0001 & $<0.0001$ & $<0.0001$ \\
\hline
\end{tabular}

$\mathrm{x}$ Treatment abbreviations defined in Table 1 .

${ }^{\mathrm{y}}$ M. phaseolina colony-forming units per bag (CFU/bag). Treatments followed by the same letter within a column are not significantly different according to Fisher's protected LSD test $(\alpha=0.05)$.

${ }^{\mathrm{z}}$ Probability of a greater $F$ value. Probability associated with type III test of fixed effects.

Table 8. Treatments applied to soil by shank injection with three-knife single-port rig in a field at the Gulf Coast Research and Education Center in Balm, FL, in 2015 and their effects on inoculum of Macrophomina phaseolina at different bed locations

\begin{tabular}{|c|c|c|c|c|}
\hline \multirow[b]{2}{*}{ Treatments $^{\mathrm{x}}$} & \multirow[b]{2}{*}{ Rate } & \multicolumn{3}{|c|}{ M. phaseolina $(\mathrm{CFU} / \mathrm{bag})^{\mathrm{y}}$} \\
\hline & & $7.6 \mathrm{~cm}$, center & $20.3 \mathrm{~cm}$, center & $7.6 \mathrm{~cm}$, side \\
\hline Dominus & 280.2 liters/ha & $3.1 \mathrm{c}$ & $1.8 \mathrm{bc}$ & $1.1 \mathrm{c}$ \\
\hline $\mathrm{AITC}+\mathrm{Pic}$ & $392 \mathrm{~kg} / \mathrm{ha}$ & $1.0 \mathrm{c}$ & $0.5 \mathrm{c}$ & $0.7 \mathrm{c}$ \\
\hline $\mathrm{AITC}+\mathrm{Pic}+1,3-\mathrm{D}$ & $392 \mathrm{~kg} / \mathrm{ha}$ & $1.7 \mathrm{c}$ & $1.3 \mathrm{c}$ & $0.5 \mathrm{c}$ \\
\hline AITC+Pic60 & $392 \mathrm{~kg} / \mathrm{ha}$ & $0.9 \mathrm{c}$ & $1.1 \mathrm{c}$ & $0.5 \mathrm{c}$ \\
\hline Pic60 & $336 \mathrm{~kg} / \mathrm{ha}$ & $57.9 \mathrm{~b}$ & $9.7 \mathrm{~b}$ & $37.4 \mathrm{~b}$ \\
\hline NTC & $\ldots$ & $3,930.5 \mathrm{a}$ & $1,315.9 \mathrm{a}$ & $3,485.3 \mathrm{a}$ \\
\hline $\operatorname{Pr}>F^{\mathrm{z}}$ & & $<0.0001$ & $<0.0001$ & $<0.0001$ \\
\hline
\end{tabular}

${ }^{\mathrm{x}}$ Treatment abbreviations defined in Table 1 .

${ }^{\mathrm{y}}$ M. phaseolina colony-forming units per bag (CFU/bag). Treatments followed by the same letter within a column are not significantly different according to Fisher's protected LSD test $(\alpha=0.05)$.

${ }^{\text {z }}$ Probability of a greater $F$ value. Probability associated with type III test of fixed effects. 
to the plant roots; however, position and number of drip tapes, volume and concentration of the product, and soil moisture and texture can dramatically influence the effective distribution and volatilization of the fumigant (Chamorro et al. 2016; Duerksen and Ajwa 2004) and often explain the inconsistencies observed between AITC treatments.

Dormant structures of pathogens, such as microsclerotia produced by M. phaseolina, are generally more resistant to fumigant action and can survive for long periods in the soil (Dhingra and Sinclair 1975; James 1989; Zveibil et al. 2012). Thus, the overall performance of AITC treatments in this study against $M$. phaseolina on strawberry is promising because it could effectively manage other soilborne pathogens such as Fusarium spp., Phytophthora spp., Verticillium dahliae, and other pathogens present not only in strawberry fields but also in other horticultural crops. Chellemi et al. (2016) reported suppression in $V$. dahliae in a strawberry field with high incidence of Verticillium wilt (11 to 35\%) when Dominus was applied through the drip system as a crop termination fumigant.

AITC treatments used in this study were shown to be a promising alternative to $\mathrm{MeBr}$, especially owing to the nature of its active ingredient, because it naturally occurs as a plant defense component within the Brassicaceae family (Brown et al. 1991). Moreover, in 2016, a petition to the USDA National Organic Program was submitted for approval of the commercial product, Dominus, to be used in organic production systems (Janis 2016). It is known that the application of AITC-derived products and the use of residues of Brassica plants to amend soil have already been reported to reduce soil populations of M. phaseolina (Lodha et al. 1997; Mazzola et al.
2017). Brassica plants are known to release isothiocyanates during the breakdown of glucosinolates in their tissues, which can inhibit the growth of certain soilborne pathogens (Angus et al. 1994; Brown et al. 1991). However, to achieve a desirable level of pest control, growers would need to incorporate large amounts of Brassica material into the soil. Morra and Kirkegaard (2002) demonstrated that 4 days after incorporation of Brassica napus and Brassica juncea, little production of isothiocyanates was detected in the soil, suggesting that improvements in controlling soilborne pests with these methods could be achieved with higher or more concentrated rates. Moreover, Mazzola et al. (2017) reported that Brassica seed meal soil amendment into the strawberry production system provided partial control of charcoal rot but did not reduce disease development compared with the NTC. Furthermore, Brassica plants are typically considered cool-season annuals adapted to short day length that grow poorly under high temperatures $\left(30^{\circ} \mathrm{C}\right)$. When grown as a winter annual, they are usually known for presenting better development and can provide more than $80 \%$ soil coverage when used as a winter cover crop (Haramoto and Gallandt 2004). Therefore, the use of Brassica plants as a summer cover crop during the strawberry off season in Florida is not considered a viable integrated pest management cover-cropping practice for growers. Thus, the only option would be to import tons of Brassica materials from other production areas, which would be logistically difficult and expensive. Therefore, a commercial product providing the active ingredient within AITC with lower application volumes is a promising soil fumigant alternative. Furthermore, the addition of commercial formulations of the biofumigant AITC to

Table 9. Treatments applied to soil by shank injection with three-knife dual-port rig in a field at the Gulf Coast Research and Education Center in Balm, FL, in 2015 and their effects on inoculum of Macrophomina phaseolina at different bed locations

\begin{tabular}{|c|c|c|c|c|}
\hline \multirow[b]{2}{*}{ Treatments $^{x}$} & \multirow[b]{2}{*}{ Rate } & \multicolumn{3}{|c|}{ M. phaseolina $(\mathrm{CFU} / \mathrm{bag})^{\mathrm{y}}$} \\
\hline & & $7.6 \mathrm{~cm}$, center & $20.3 \mathrm{~cm}$, center & $7.6 \mathrm{~cm}$, side \\
\hline Dominus & 280.2 liters/ha & $2.2 \mathrm{c}$ & $2.2 \mathrm{c}$ & $0.5 \mathrm{c}$ \\
\hline AITC+Pic & $308 \mathrm{~kg} / \mathrm{ha}$ & $1.7 \mathrm{c}$ & $2.2 \mathrm{c}$ & $0.7 \mathrm{c}$ \\
\hline $\mathrm{AITC}+\mathrm{Pic}$ & $392 \mathrm{~kg} / \mathrm{ha}$ & $0.7 \mathrm{c}$ & $0.5 \mathrm{c}$ & $0.5 \mathrm{c}$ \\
\hline $\mathrm{AITC}+\mathrm{Pic}+1,3-\mathrm{D}$ & $308 \mathrm{~kg} / \mathrm{ha}$ & $0.7 \mathrm{c}$ & $0.7 \mathrm{c}$ & $1.2 \mathrm{c}$ \\
\hline AITC+Pic+1,3-D & $392 \mathrm{~kg} / \mathrm{ha}$ & $1.4 \mathrm{c}$ & $1.1 \mathrm{c}$ & $1.1 \mathrm{c}$ \\
\hline AITC+Pic60 & 308 kg/ha & $0.7 \mathrm{c}$ & $0.8 \mathrm{c}$ & $0.7 \mathrm{c}$ \\
\hline AITC+Pic60 & $392 \mathrm{~kg} / \mathrm{ha}$ & $0.5 \mathrm{c}$ & $1.3 \mathrm{c}$ & $1.4 \mathrm{c}$ \\
\hline Pic60 & $336 \mathrm{~kg} / \mathrm{ha}$ & $588.2 \mathrm{~b}$ & $26.6 \mathrm{~b}$ & $88.7 \mathrm{~b}$ \\
\hline NTC & $\ldots$ & $2,379.3 \mathrm{a}$ & $3,263.4 \mathrm{a}$ & $2,726.1 \mathrm{a}$ \\
\hline $\operatorname{Pr}>F^{\mathrm{z}}$ & & $<0.0001$ & $<0.0001$ & $<0.0001$ \\
\hline
\end{tabular}

$\mathrm{x}$ Treatment abbreviations defined in Table 1.

${ }^{\mathrm{y}}$ M. phaseolina colony-forming units per bag (CFU/bag). Treatments followed by the same letter within a column are not significantly different according to

Fisher's protected LSD test $(\alpha=0.05)$.

${ }^{\mathrm{z}}$ Probability of a greater $F$ value. Probability associated with type III test of fixed effects.

Table 10. Treatments applied to soil by shank injection with two-knife single-port rig or drip (one tape) in a field at the Florida Strawberry Growers Association facility in Dover, FL, in 2015 to 2016 and their effects on inoculum of Macrophomina phaseolina at different bed locations

\begin{tabular}{|c|c|c|c|c|c|}
\hline \multirow[b]{2}{*}{ Treatments ${ }^{w}$} & \multirow[b]{2}{*}{ Rate } & \multicolumn{3}{|c|}{ M. phaseolina $(\mathrm{CFU} / \mathrm{bag})^{\mathrm{x}}$} & \multirow[b]{2}{*}{$\operatorname{Pr}>F^{y}$} \\
\hline & & $7.6 \mathrm{~cm}$, center & $20.3 \mathrm{~cm}$, center & $7.6 \mathrm{~cm}$, side & \\
\hline MeBr67 & $392.0 \mathrm{~kg} / \mathrm{ha}$ & $4.1 \mathrm{c}$ & $2.3 \mathrm{~d}$ & $1.4 \mathrm{~d}$ & 0.5859 \\
\hline MeBr50 & $358.4 \mathrm{~kg} / \mathrm{ha}$ & $6.8 \mathrm{c}$ & $4.0 \mathrm{~cd}$ & $14.2 \mathrm{~cd}$ & 0.459 \\
\hline $\mathrm{C} 35$ & 280.2 liters/ha & $144.6 \mathrm{ab}$ & $135.5 \mathrm{~b}$ & $61.9 \mathrm{bc}$ & 0.6662 \\
\hline Pic60 & $336 \mathrm{~kg} / \mathrm{ha}$ & $1,017.9 \mathrm{a}$ & $1,068.1 \mathrm{a}$ & $77.7 \mathrm{bc}$ & 0.1302 \\
\hline $\mathrm{AITC}+\mathrm{Pic}$ & 448 kg/ha & $29.8 \mathrm{bc}$ & $10.9 \mathrm{c}$ & $248.4 \mathrm{ab}$ & 0.0081 \\
\hline Metam potassium & 560.4 liters/ha & $14.2 \mathrm{c}$ & $17.9 \mathrm{c}$ & $216.0 \mathrm{ab}$ & 0.0355 \\
\hline Dominus & 233.5 liters/ha & $7.6 \mathrm{c}$ & $6.8 \mathrm{~cd}$ & $469.6 \mathrm{ab}$ & 0.0005 \\
\hline AITC+Pic & $364 \mathrm{~kg} / \mathrm{ha}$ & $16.5 \mathrm{bc}$ & $4.1 \mathrm{~cd}$ & $2,259.8 \mathrm{a}$ & $<0.0001$ \\
\hline NTC & $\ldots$ & $1,086.2 \mathrm{a}$ & $1,905.9 \mathrm{a}$ & $579.6 \mathrm{ab}$ & 0.4871 \\
\hline $\operatorname{Pr}>F^{\mathrm{z}}$ & & 0.0002 & $<0.0001$ & 0.0003 & $\ldots$ \\
\hline
\end{tabular}

${ }^{w}$ Treatment abbreviations defined in Table 1. Metam potassium, Dominus, and both rates of AITC+Pic were applied through drip tape. The remainder of the treatments were applied via shank injection.

x M. phaseolina colony-forming units per bag (CFU/bag). Treatments followed by the same letter within a column are not significantly different according to Fisher's protected LSD test $(\alpha=0.05)$.

y Probability associated with test of effect slices for local $\times$ treatment interaction, sliced by treatment.

z Probability of a greater $F$ value. Probability associated with type III test of fixed effects for treatments within each location. 
the list of alternative soil fumigants allows growers to choose among the products and adopt the one that is most suitable and feasible for their specific soil conditions and disinfestation needs throughout the year.

Results from the eight trials presented in this study show that formulations of the biofumigant AITC were overall as effective or more effective than standard soil fumigants used in strawberry for reducing populations of M. phaseolina in the soil. However, uniform distribution in the soil is challenging but key for effective disease control. Our results suggest that preplant fumigation of AITC treatments via shank with a dual port rig could be recommended at the formation of new plastic-mulched beds. In the case that plastic beds from previous seasons are being reused, application through two drip tapes showed to be more effective in reducing inoculum at the side of the beds than one drip tape. Nevertheless, if the use of two drip tapes is not possible, the combination of AITC and chloropicrin applied by one drip tape may help distribution of the AITC material and have a better chance to reach and to reduce $M$. phaseolina populations at the side of the beds. Therefore, AITC shows to be a promising alternative to manage charcoal rot, for both conventional and organic growers, but novel means to improve application technology should be evaluated to improve disease control.

\section{Literature Cited}

Ajwa, H. A., Trout, T., Mueller, J., Wilhelm, S., Nelson, S. D., Soppe, R., and Shatley, D. 2002. Application of alternative fumigants through drip irrigation systems. Phytopathology 92:1349-1355.

Angus, J. F., Gardner, P. A., Kirkegaard, J. A., and Deshmarchelier, J. M. 1994. Biofumigation: Isothiocyanates released from Brassica roots inhibit growth of the take all fungus. Plant Soil 162:107-112.

Avilés, M., Castillo, S., Bascón, J., Zea-Bonilla, T., Martín-Sánchez, P. M., and Pérez-Jiménez, R. M. 2008. First report of Macrophomina phaseolina causing crown and root rot of strawberry in Spain. Plant Pathol. 57:382.

Boyd, N. S., Vallad, G., Wu, F., Noling, J., and Guan, Z. 2017. Placement of metam potassium in combination with dimethyl disulfide, chloropicrin, and 1,3-dichloropropene for Cyperus rotundus $\mathrm{L}$. and broadleaf weed control in tomato (Solanum lycopersicum L.). Crop Prot. 100:45-50.

Brown, P. D., Morra, M. J., McCaffrey, J. P., Auld, D. L., and Williams, L. 1991. Allelochemicals produced during glucosinolate degradation in soil. J. Chem. Ecol. 17:2021-2034.

Chamorro, M., Domínguez, P., Medina, J. J., Miranda, L., Soria, C., Romero, F., López-Aranda, J. M., Daugovish, O., Mertely, J., and De los Santos, B. 2015. Assessment of chemical and biosolarization treatments for the control of Macrophomina phaseolina in strawberries. Sci. Hortic. (Amsterdam) 192: 361-368.

Chamorro, M., Seijo, T. E., Noling, J. C., De los Santos, B., and Peres, N. A. 2016. Efficacy of fumigant treatments and inoculum placement on control of Macrophomina phaseolina in strawberry beds. Crop Prot. 90:163-169.

Chellemi, D. O., Katan, G. A., and Subbarao, K. V. 2016. Development and deployment of systems-based approaches for the management of soilborne plant pathogens. Phytopahtology 106:216-225.

Devkota, P., and Norsworthy, J. K. 2014. Allyl isothiocyanate and metham sodium as methyl bromide alternatives for weed control in plasticulture tomato. Weed Technol. 28:377-384.

Dhingra, O. D., and Sinclair, J. B. 1975. Survival of Macrophomina phaseolina sclerotia in soil: Effects of soil moisture, carbon:nitrogen ratios, carbon sources, and nitrogen concentrations. Phytopathology 65:236-240.

Dhingra, O. D., and Sinclair, J. B., eds. 1978. Biology and Pathology of Macrophomina phaseolina. Universidade Federal de Vicosa, Minas Gerais, Brazil.

Duerksen, C., and Ajwa, H. 2004. Drip fumigation with K-Pam HL and Vapam HL In: Annual International Research Conference on Methyl Bromide Alternatives and Emissions Reductions. http://ucanr.edu/sites/mb3/files/73583.pdf

Duniway, J. M. 2002. Status of chemical alternatives to methyl bromide for preplant fumigation of soil. Phytopathology 92:1337-1343.

Fennimore, S. A., Serohijos, R., Samtani, J., Ajwa, H. A., Subbarao, K., Martin, F. N., Daugovish, O., Legard, D., Browne, G. T., Muramoto, J., Shennan, C., and Klonsky, K. 2013. TIF film, substrates and nonfumigant soil disinfestation maintain fruit yields. Calif. Agric. 67:139-146.

Gupta, G. K., Sharma, S. K., and Ramteke, R. 2012. Biology, epidemiology and management of the pathogenic fungus Macrophomina phaseolina (Tassi) Goid with special reference to charcoal rot of soybean (Glycine $\max (\mathrm{L}$.) Merrill). J. Phytopathol. 160:167-180.

Guthman, J. 2016. Going both ways: More chemicals, more organics, and the significance of land in post-methyl bromide fumigation decisions for California's strawberry industry. J. Rural Stud. 47:76-84.

Haramoto, E. R., and Gallandt, E. R. 2004. Brassica cover cropping for weed management: A review. Renew. Agric. Food Syst. 19:187-198.
Hartz, T. K., Carter, W. W., and Bruton, B. D. 1987. Failure of fumigation and solarization to control Macrophomina phaseolina and subsequent muskmelon vine decline. Crop Prot. 6:261-264.

Isagro. 2013. Dominus ${ }^{\mathrm{TM}}$ : IRF135 (AITC), biofumigant-A regulatory and development update. In: 2013 Annual International Research Conference on Methyl Bromide Alternatives and Emissions Reductions, San Diego, CA, November 4, 2013.

Isagro. 2017a. Dominus ${ }^{\circledR}-$ Where is Dominus ${ }^{\circledR}$ registered? Online publication. http://www.isagro-usa.com/dominus.html

Isagro. 2017b. Non-microbial fumigants for control of nematodes, soil diseases and weeds. IR-4 Training Workshop 2017. Online publication. http://wrir4 ucdavis.edu/events/2017_SLR_Meeting/Presentations/NematodeManagement/ $3 \% 20$ Stallings $\% 202017 \% 20 \% 20$ NonMicrobial $\% 20$ FumigantsNematacides $\%$ 20CO\%202017.pdf

James, R. L. 1989. Effects of Fumigation on Soil Pathogens and Beneficial Microorganisms. Pages 29-33 in: Proceedings, Intermountain Forest Nursery Association, Bismarck, ND. T. D. Landis, ed. General Technical Report RM184. U.S. Department of Agriculture, Forest Service, Rocky Mountain Forest and Range Experiment Station, Fort Collins, CO. https://rngr.net/publications/ proceedings/1989/james.pdf

Janis, J. 2016. Allyl isothiocyanate: Petition for inclusion on the national list for use in organic crop production. Isagro, Morrisville, NC.

Kaur, S., Dhillon, G. S., Brar, S. K., Vallad, G. E., Chand, R., and Chauhan, V. B 2012. Emerging phytopathogen Macrophomina phaseolina: Biology, economic importance and current diagnostic trends. Crit. Rev. Microbiol. 38:136-151.

Koike, S. T., Arias, R.S., Hogan, C. S., Martin, F. N., and Gordon, T. R. 2016. Status of Macrophomina phaseolina on strawberry in California and preliminary characterization of the pathogen. Int. J. Fruit Sci. 16(sup1):148-159.

Lodha, S., Sharma, S. K., and Aggarwal, R. K. 1997. Solarization and natural heating of irrigated soil amended with cruciferous residues for improved control of Macrophomina phaseolina. Plant Pathol. 46:186-190.

Mazzola, M. 2011. Active manipulation of resident biology to suppress Macrophomina phaseolina in strawberry. Phytopathology 101:S117.

Mazzola, M., Agostini, A., and Cohen, M. F. 2017. Incorporation of Brassica seed meal soil amendment and wheat cultivation for control of Macrophomina phaseolina in strawberry. Eur. J. Plant Pathol. 149:57-71.

McGovern, R. J. 2015. Management of tomato diseases caused by Fusarium oxysporum. Crop Prot. 73:78-92.

McGovern, R. J., Vavrina, C. S., Noling, J. W., Datnoff, L. A., and Yonce, H. D. 1998. Evaluation of application methods of metam sodium for management of Fusarium crown and root rot in tomato in southwest Florida. Plant Dis. 82: 919-923.

Mertely, J. C., Seijo, T., and Peres, N. A. 2005. First report of Macrophomina phaseolina causing a crown rot of strawberry in Florida. Plant Dis. 89:434.

Mihail, J. D. 1989. Macrophomina phaseolina: Spatio-temporal dynamics of inoculum and of disease in a highly susceptible crop. Phytopathology 79: 848-855.

Mihail, J. D. 1992. Macrophomina. Pages 134-136 in: Methods for Research on Soilborne Phytopathogenic Fungi. L. S. Singleton, J. D. Mihail, and C. M. Rush, eds. American Phytopathological Society, St. Paul, MN.

Morra, M. J., and Kirkegaard, J. A. 2002. Isothiocyanate release from soilincorporated Brassica tissues. Soil Biol. Biochem. 34:1683-1690.

Noling, J. W. 2015. Fumigant Nematicides Registered for Vegetable Crop Use in Florida. ENY-064. UF/IFAS Extension, Gainesville, FL.

Noling, J. W., Botts, D. A., and MacRae, A. W. 2011. Alternatives to methyl bromide soil fumigation for Florida vegetable production. Pages 47-54 in: Vegetable Production Handbook. UF/IFAS Extension-Horticultural Sciences, Gainesville, FL. http://hos.ufl.edu/Vegetarian/10/Jan/VPH\%202010-2011/Chap\%206.pdf.

Noling, J. W., Schumann, A. W., Crow, W. T., and Cody, M. 2015. Assessing sting nematode impact and soil fumigant performance using measures of strawberry canopy greenness. J. Nematol. 47:260.

Ntalli, N., and Caboni, P. 2017. A review of isothiocyanates biofumigation activity on plant parasitic nematodes. Phytochem. Rev. 16:827-834

O'Neil, M. J., ed. 2013. The Merck Index-An Encyclopedia of Chemicals, Drugs, and Biologicals. Page 557. Royal Society of Chemistry, Cambridge, UK.

Pastrana, A. M., Capote, N., De los Santos, B., Romero, F., and Basallote-Ureba, M. J. 2014. First report of Fusarium solani causing crown and root rot on strawberry crops in southwestern Spain. Plant Dis. 98:161.

Porter, I., Mattner, S., Mann, R., and Gounder, R. 2004. Strawberry nurseries: Summaries of alternatives to methyl bromide fumigation and trials in different geographic regions. Proceedings of the International Conference on Alternatives to Methyl Bromide. Lisbon, Portugal, 27-30 September.

Pratt, R. G. 2006. A direct observation technique for evaluating sclerotium germination by Macrophomina phaseolina, and effects of biocontrol materials on survival of sclerotia in soil. Mycopathologia 162:121-131.

Ristaino, J. B., and Thomas, W. 1997. Agriculture, methyl bromide, and the ozone hole: Can we fill the gaps? Plant Dis. 81:964-977.

Sánchez, S., Gambardella, M., Henríquez, J. L., and Díaz, I. 2013. First report of crown rot of strawberry caused by Macrophomina phaseolina in Chile. Plant Dis. 97:996.

Schneider, S. M., Hanson, B. D., Gerik, J. S., Shrestha, A., Trout, T. J., and Gao, S. 2009. Comparison of shank- and drip- applied methyl bromide alternatives in perennial crop field nurseries. HortTechnol. 19:331-339. 
Short, D. P. G., Sandoya, G., Vallad, G. V., Koike, S. T., Xiao, C. L., Wu, B. M., Gurung, S., Hayes, R. J., and Subbarao, K. V. 2015. Dynamics of Verticillium species microsclerotia in field soils in response to fumigation, cropping patterns, and flooding. Phytopathol. 105:638-645.

Short, G. E., Wyllie, T. D., and Ammon, V. D. 1978. Quantitative enumeration of Macrophomina phaseolina in soybean tissues. Phytopathol. 68:736-741.

Spurlock, F., Johnson, B., Tuli, A., Gao, S., Tao, J., Sartori, F., Qin, R., Sullivan, D., Stanghellini, M., and Ajwa, H. 2013. Simulation of fumigant transport and volatilization from tarped broadcast applications. Online publication. Vadose Zone J. 12.

Su, G., Suh, S. O., Schneider, R. W., and Russin, J. S. 2001. Host specialization in the charcoal rot fungus, Macrophomina phaseolina. Phytopathology 91: 120-126.

Sun, S., Wang, X., Zhu, Z., Wang, B., and Wang, M. 2015. Occurrence of charcoal rot caused by Macrophomina phaseolina, an emerging disease of adzuki bean in China. J. Phytol. 164:212-216.
U.S. EPA. n.d. Critical use exemption information. United States Environmental Protection Agency, Washington, DC. https://www.epa.gov/ozone/mbr/cueinfo.html Wang, D., and Yates, S. R. 1999. Spatial and temporal distributions of 1,3dichloropropene in soil under drip and shank application and implications for pest control efficacy using concentration-time index. Pestic. Sci. 55:154-160.

Watanabe, T., Smith, R. S., and Snyder, W. C. 1970. Populations of Macrophomina phaseoli in soil as affected by fumigation and cropping. Phytopathology 60: 1717-1719.

Zhang, Y. Y., Yu, Y., Wang, K., Li, M., Xu, D. S., and Zhao, J. 2016. First report of sunflower charcoal rot caused by Macrophomina phaseolina in Jilin and Inner Mongolia, China. Plant Dis. 100:1494.

Zveibil, A., and Freeman, S. 2005. First report of crown and root rot in strawberry caused by Macrophomina phaseolina in Israel. Plant Dis. 89:1014.

Zveibil, A., Mor, N., Gnayem, N., and Freeman, S. 2012. Survival, host-pathogen interaction, and management of Macrophomina phaseolina on strawberry in Israel. Plant Dis. 96:265-272 